
TAB. XXXIII., Fig. 1.

\title{
CARDUELIS CANICEPS.
}

\author{
Card. brunnescenti-canus; alis caudâque nigris; circulo angusto frontem rictum gulamque \\ circumcingente coccineo; fasciâ alarum aureâ; thorace, maculis paucis alarum, uropygio, \\ abdomine imo, crisso, rectricum externarum pogoniis internis, mediarumque apicibus albis. \\ Statura Card. communis.
}

THE fact that many of the most common birds of the British Isles are represented by species similar, though perfectly distinct, in some of the remotest regions of the globe, is nowhere more strongly illustrated than in the present instance, the Carduelis caniceps, which, although differing in several respects, is not, as may at first sight be perceived, a perfect Goldfinch. The general form and the disposition of the colours, the red front, and more particularly the gold markings on the wing, at once remind the English naturalist of his native species. No account of its habits has reached uș, but it appears to be a bird of rare occurrence.

The forehead, the superciliary line, base of the under mandible, and throat, are scarlet; the top of the head, occiput and back, olive grey; the wings are black with a golden band; the rump white; the tail black, the tips of the two middle and the inner webs of the two external feathers being white; the under surface is pale brownish grey; beak and tarsi flesh colour.

TAB. XXXIII., Fig. 2.

\section{CARDUELIS SPINOÏDES。}

Mas. Card. fronte, occipite, collo corporeque infra, ptilis, pteromatum apicibus, fasciâ remigum, rectricumque lateralium basibus favis; capite supra dorsoque olivaceis; alis caudâque fuscescenti-nigris.

Fœm.? Coloribus minùs saturatis ; abdomine dorsoque olivaceo-fusco striatis.

Statura paulò major quàm Card. Spini.

THE near relation which this species bears to our Aberdevine, or Siskin, is no less obvious and singular than that of the last to the Goldfinch; and it is an interesting point, which the naturalist will not fail to remark, that two birds which are so closely connected in form and locality in our own climate, should each have its distinct though close representative assimilated equally in exterior appearance as well as local distribution in a country so far apart from us as the Himalayan mountains.

To the habits of this species much the same observations will apply as those of the one preceding; the Siskin being the most probable type to be looked to in its mode of life and means of subsistence.

The forehead, occiput, sides of the neck, shoulders, tips of the greater coverts, and outer webs at the basal extremity of the quills, are yellow; the back olive brown, the quills and tail having a blackish tinge at their tips, the feathers of the latter being yellow at their base; the beak is flesh colour with a dark culmen; the tarsi are of a pale flesh colour.

Both these species are figured of their natural size. 


\section{$2 \mathrm{BHL}$ Biodiversity Heritage Library}

Gould, John. 1831. "Carduelis caniceps [Tab. XXXIII]." A century of birds from the Himalaya Mountains -. https://doi.org/10.5962/p.323583.

View This Item Online: https://www.biodiversitylibrary.org/item/132967

DOI: https://doi.org/10.5962/p.323583

Permalink: https://www.biodiversitylibrary.org/partpdf/323583

\section{Holding Institution}

Smithsonian Libraries

\section{Sponsored by}

Biodiversity Heritage Library

\section{Copyright \& Reuse}

Copyright Status: Public domain. The BHL considers that this work is no longer under copyright protection.

This document was created from content at the Biodiversity Heritage Library, the world's largest open access digital library for biodiversity literature and archives. Visit BHL at https://www.biodiversitylibrary.org. 